\title{
THREE GENERATIONS UNDER ONE ROOF? BAYESIAN MODELING OF RADIOCARBON DATA FROM NUNALLEQ, YUKON-KUSKOKWIM DELTA, ALASKA
}

\author{
Paul M. Ledger, Véronique Forbes, Edouard Masson-Maclean, Charlotta Hillerdal,
} W. Derek Hamilton, Ellen McManus-Fry, Ana Jorge, Kate Britton, and Richard A. Knecht

\begin{abstract}
This article presents the results of a program of radiocarbon dating and Bayesian modeling from the precontact Yup' $i k$ site of Nunalleq (GDN-248) in subarctic southwestern Alaska. Nunalleq is deeply stratified, presenting a robust relative chronological framework of well-defined individual house floors abundant in ecofacts suitable for radiocarbon dating. Capitalizing on this potential, we present the results of one of the first applications of Bayesian statistical modeling of radiocarbon data from an archaeological site in the North American Arctic. Using these methods, we demonstrate that it is possible to generate robust, high-resolution chronological models from Arctic archaeology. Radiocarbon dates, procured prior to the program of dating and modeling presented here, suggested an approximately three-century duration of occupation at the site. The results of Bayesian modeling nuance this interpretation. While it is possible that there may have been activity for almost three centuries (beginning in the late fourteenth century), occupation of the dwelling complex, which dominates the site, was more likely to have endured for no more than a century. The results presented here suggest that the occupation of Nunalleq likely encompassed three generations beginning cal AD 1570-1630 before being curtailed by conflict around cal AD 1645-1675.
\end{abstract}

En este artículo se presentan los resultados de un programa de datación radiocarbónica y modelización bayesiana del sitio de Nunalleq, un yacimiento Yup'ik pre-contacto en el sudoeste sub-ártico de Alaska. Nunalleq es un yacimiento fuertemente estratificado que presenta una secuencia ocupacional compleja consistente en una serie de pisos de habitación individualizados, todos ellos contenientes abundantes ecofactos susceptibles de ser datados por radiocarbono. Explotando ese potencial, presentamos los resultados de una de las primeras aplicaciones de la modelización estadística bayesiana sobre datos radiocarbónicos para un yacimiento arqueológico del Ártico norteamericano. A través del uso de estos métodos demostramos que es posible generar modelos cronológicos consistentes y de alta resolución a partir de la arqueología del Ártico. Datos radiocarbónicos anteriores sugerían una duración de aproximadamente tres siglos para la ocupación del yacimiento. Los resultados de la modelización bayesiana matizan esta interpretación. Si bien es posible que haya habido actividad durante casi tres siglos (comenzando a finales del siglo catorce), parece más probable que la ocupación del complejo habitacional, mismo que domina el yacimiento, no haya durado más de un siglo. Los resultados expuestos en este trabajo sugieren que la ocupación de Nunalleq probablemente haya abarcado tres generaciones, comenzando en 1570-1630 cal dC y siendo truncada por un episodio bélico en torno a $1645-1675 \mathrm{cal} \mathrm{dC}$.

Bayesian modeling is becoming the preferred method for interpreting radiocarbon data from archaeological sites (Bayliss 2015). By combining archaeological knowledge of stratigraphy

\section{Paul M. Ledger, Edouard Masson-Maclean, Charlotta Hillerdal, Ellen McManus-Fry, Ana Jorge,}

and Richard A. Knecht - Department of Archaeology, School of Geosciences, University of Aberdeen, Elphinstone Road, Aberdeen AB24 3UF, UK (p.ledger@abdn.ac.uk, corresponding author)

Véronique Forbes $\square$ Department of Archaeology, Memorial University of Newfoundland, Queen's College, Prince Philip Drive, St. John's, Newfoundland, A1B 3R6, Canada; Université de Bordeaux, PACEA, UMR 5199, Bâtiment B8, Allée Geoffroy Saint Hilaire, CS 50023, 33615 Pessac CEDEX, France

W. Derek Hamilton $\square$ Scottish Universities Environmental Research Centre, University of Glasgow, Rankine Avenue, East Kilbride, G75 0QF, Scotland, UK

Kate Britton $\square$ Departament of Archaeology, University of Aberdeen, Elphinstone Road, Aberdeen AB24 3UF, UK; Department of Human Evolution, Max Planck Institute for Evolutionary Anthropology, Deutscher Platz 6, 04103, Leipzig, Germany

American Antiquity 83(3), 2018, pp. 505-524

Copyright (C) 2018 by the Society for American Archaeology doi:10.1017/aaq.2018.14 
and context (relative dating) with calibrated radiocarbon, or other chronological data (absolute dating), Bayesian statistical methods enable probabilistic models that are more robust and precise than their individual components (Bayliss 2009). A major advantage of this approach is the ability to reduce the uncertainties inherent in radiocarbon data as well as produce age estimates for undated activities and their duration. This has been widely demonstrated and has provided chronological insights across a variety of locations and time periods (e.g., Bayliss et al. 2007; Hamilton et al. 2015; Higham et al. 2011; Roberts et al. 2016). Yet despite these successes and the existence of formalized methodologies for over two decades, adoption has been comparatively slow in the Americas (Hamilton and Krus 2017). Applications to less-known archaeologies, such as that of circumpolar regions of North America, remain far from common.

Myriad problems, arising both from the climate and lifeways practiced in northern regions, constrain the development of high-resolution chronologies in the Arctic (Ledger et al. 2016) and the meaningful application of Bayesian methods. A preeminent issue is identifying samples on which to obtain accurate ${ }^{14} \mathrm{C}$ measurements. Marine resources featured heavily in the subsistence of Arctic peoples; consequently, a large proportion of the organic remains available for radiocarbon dating are affected by the marine reservoir effect (MRE; Dumond and Griffin 2002). This results in an age at death offset, since the marine and terrestrial biospheres are not in equilibrium with respect to concentrations of ${ }^{14} \mathrm{C}$. This is compounded in higher-latitude Arctic regions by the dry and cold climate, which further inhibits deep soil formation and stratigraphic (relative) chronological information. Consequently, high-resolution chronologies of precontact lifeways remain rare in the Arctic.

Unlike many sites in circumpolar North America, the precontact Yup'ik site of Nunalleq (GDN-248) in the Yukon-Kuskokwim (Y-K) delta (Figure 1) is an excellent place in which to explore the utility of Bayesian modeling. Owing to its relatively southerly subarctic location and the presence of discontinuous permafrost, the site is both deeply stratified and well preserved
(Knecht 2014). Excavations since 2009 have revealed the remains of a dwelling-part of a larger village-containing a series of welldefined, superimposed house floors (Forbes et al. 2014). In all instances, these floors are rich in terrestrial ecofacts, such as animal bone and plant remains, ideal for procuring accurate radiocarbon dates (Ledger et al. 2016).

The Y-K delta has often been considered an important region in the diffusion of cultural innovations in the Arctic and, more recently, of the Inuit peopling of circumpolar North America. Ethnographic work has illustrated that Yup'ik culture was characterized by intertribal warfare (Fienup-Riordan and Rearden 2016) and was socially, ceremonially, and technologically complex (VanStone 1984). However, precontact Yup'ik culture remains poorly defined archaeologically. Few Yup'ik sites have been excavated, and consequently, its origins, chronology, and relationship with other Inuit/Eskimo cultural groups are poorly understood (Shaw 1998). The exceptionally well-preserved and diverse material record from Nunalleq therefore offers a unique opportunity to examine almost all aspects of late precontact Yup'ik lifeways. To this end, this article presents the results of an exploration of Bayesian modeling. The principal aim of the study is to establish a robust chronological framework that will facilitate subcentennial-scale reconstructions of the cultural traditions and subsistence practices of the precontact Yup'ik lifeways at Nunalleq.

\section{Background}

\section{Regional History}

The earliest known occupation of the Y-K delta region begins with the Norton techno-cultural tradition (Shaw 1998). Norton culture sites are first found in prime coastal locations from as early as $1000 \mathrm{BC}$, and at more marginal coastal sites from about 400 to 200 BC (Shaw 1998). As population density in coastal areas increased, Norton groups gradually began to expand inland around the turn of the first millennium to exploit the tundra wetlands of the delta. This growth period is placed between circa AD 400 and AD 1000 and defined by Shaw (1982) as the 

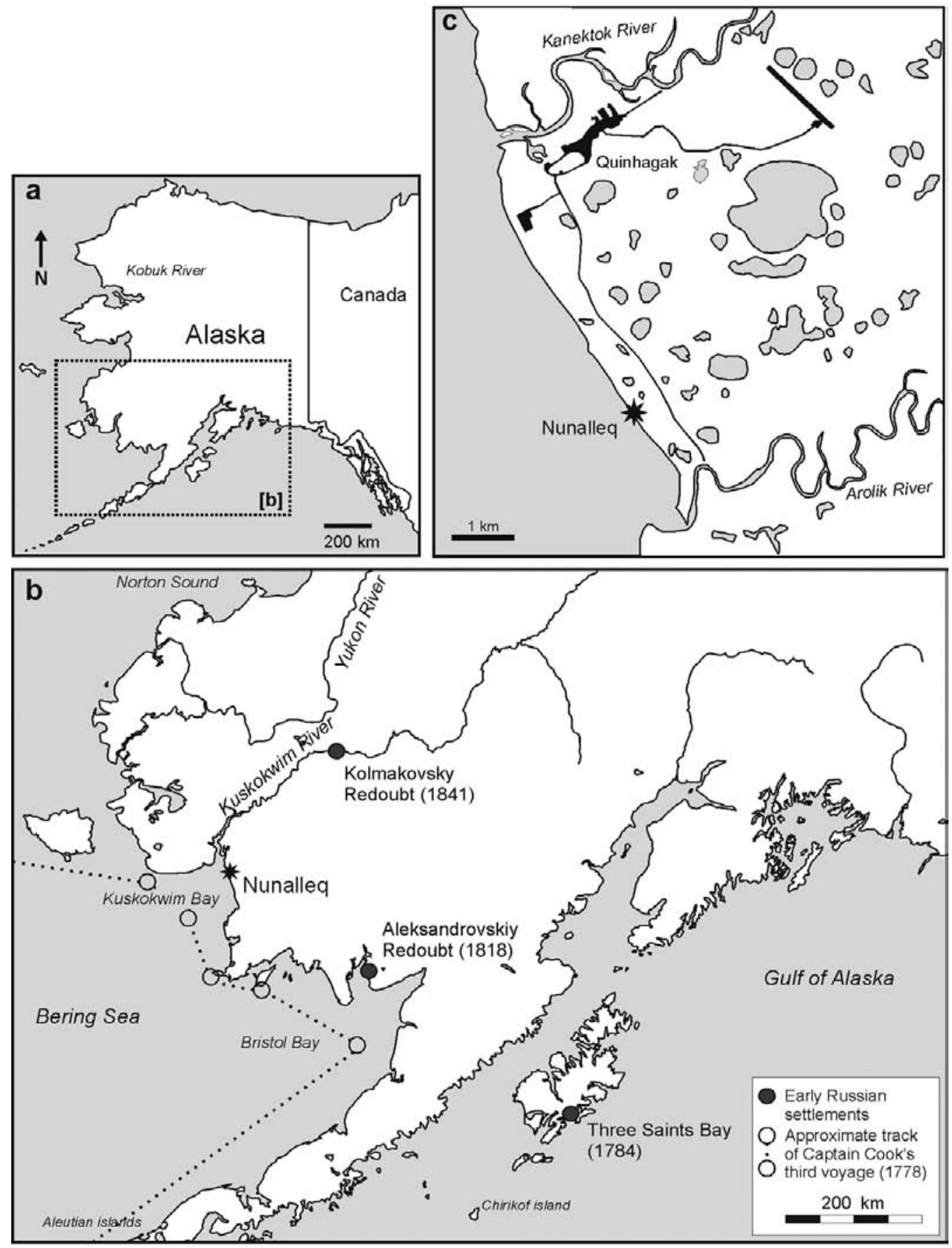

Figure 1. (a) Location of Nunalleq within Alaska, (b) southwestern Alaska illustrating the location of Nunalleq and known Euro-American activities and settlement locations in the eighteenth through nineteenth centuries, and (c) local geography in the vicinity of Nunalleq. Maps drawn by the authors. 
Yukon-Kuskokwim Delta phase of the Norton tradition. The chronology of the following millennium is poorly understood (Shaw 1982); however, the Norton tradition was likely replaced or evolved under the influence of the Western Thule tradition, believed to have spread southward from northern Alaska sometime after AD 1000 (Friesen and Mason 2016). Unfortunately, owing to an absence of widespread archaeological investigation in the Y-K delta, pinpointing the emergence and regional development of Yup'ik culture is difficult. Yup'ik material culture is recorded immediately north of the Y-K delta in the Norton Sound region from at least the fourteenth century - and potentially earlier - at the site of Shaktoolik (NOB-072; Darwent et al. 2017). Similarly, oral histories recorded in the region by the Bureau of Indian Affairs have been read as an indication of Yup'ik peoples in the delta from at least the fifteenth century. The late prehistoric period is notable for the Bow and Arrow Wars, an ethnographically documented period of warfare (e.g., Fienup-Riordan and Rearden 2016; Nelson 1899). The chronology of this conflict-in terms of its beginning and duration-is poorly constrained; however, it is clear that it was widespread, leading to both the destruction of villages and population migrations (Pratt 2013). The historic period in the Y-K delta begins with the arrival of the Euro-Americans from the late eighteenth to early nineteenth century. Russian exploration of Alaska began in 1741 and was followed by the arrival of independent fur hunters from the mid-1740s and a permanent outpost at Three Saints Bay (Figure 1) on Kodiak Island in 1784 (Postinikov and Falk 2015). Initial Russian explorations of the Bristol Bay region were likely contemporary with this first settlement (Black 1984), although the British mariner Captain Cook had previously charted Bristol and anchored in Kuskokwim Bay in 1778 on his way north (Postinikov and Falk 2015). Russians established the fur trading post of Aleksandrovskiy Redoubt on Bristol Bay (Dumond and VanStone 1995) in 1818, and a party led by Petr Korsakovskiy reached Kuskokwim Bay in 1819 (VanStone 1973). Kolmakovsky Redoubt on the middle Kuskokwim Bay was established later, in 1841 (Oswalt 1980).

\section{The Nunalleq Excavations}

Nunalleq is located on the Bering Sea coast of southwest Alaska (Figure 1). Prior to the commencement of archaeological excavations, the site had long been known to residents of the local village of Quinhagak, located approximately 5 $\mathrm{km}$ to the north (Fienup-Riordan et al. 2015). Local oral histories record the location as that of the village of Agalig, which was destroyed in the Bow and Arrow Wars of the precontact era and over time came to be known as Nunalleq, or old village (Fienup-Riordan and Rearden 2016; Pratt 2013). In 2009, Rick Knecht was invited by Qanirtuuq Incorporated (the local Alaska Native village corporation) to examine the site, at which time rescue excavations were initiated (Knecht 2014). These continued in 2010, focusing on the western portion of the site (Area C), which was subsequently lost to coastal erosion. In 2012, a new $10 \times 10 \mathrm{~m}$ excavation block (Area D) was opened extending eastward from the 2011 erosion face. The following year (2013), openarea excavations and single-context recording were adopted. Two new excavation blocks were created in 2013: a $14 \times 12 \mathrm{~m}$ block focusing on the collapsed dwelling (Area A) and refuse deposits immediately north (Area B). Area A was subsequently expanded to $14 \times 16 \mathrm{~m}$ in 2015 (Figure 2). The deposits excavated in Area $\mathrm{B}$ and Area A likely reflect the respective north and eastward lateral extents of the site. A trench $(3.5 \times 1.5 \times 0.6 \mathrm{~m})$ excavated approximately $25 \mathrm{~m}$ east of Area A (Figure 2) to collect samples for paleoenvironmental analysis produced no archaeological features. Occasionally, small fragments of worked wood were noted in a layer of herbaceous peat at between 33 and $25 \mathrm{~cm}$ below ground surface. Paleoenvironmental analyses indicate that this herbaceous peat layer reflects the land surface contemporary with the occupation of the site (Ledger 2018). The southward extent of the site is less clearly defined, although potential archaeological features approximately $70 \mathrm{~m}$ southeast of Area A are currently under investigation.

To date, excavations in Area A have revealed the partial remains of a multiroomed sod- and wood-built dwelling that likely formed part of a larger village. At least three different occupation 


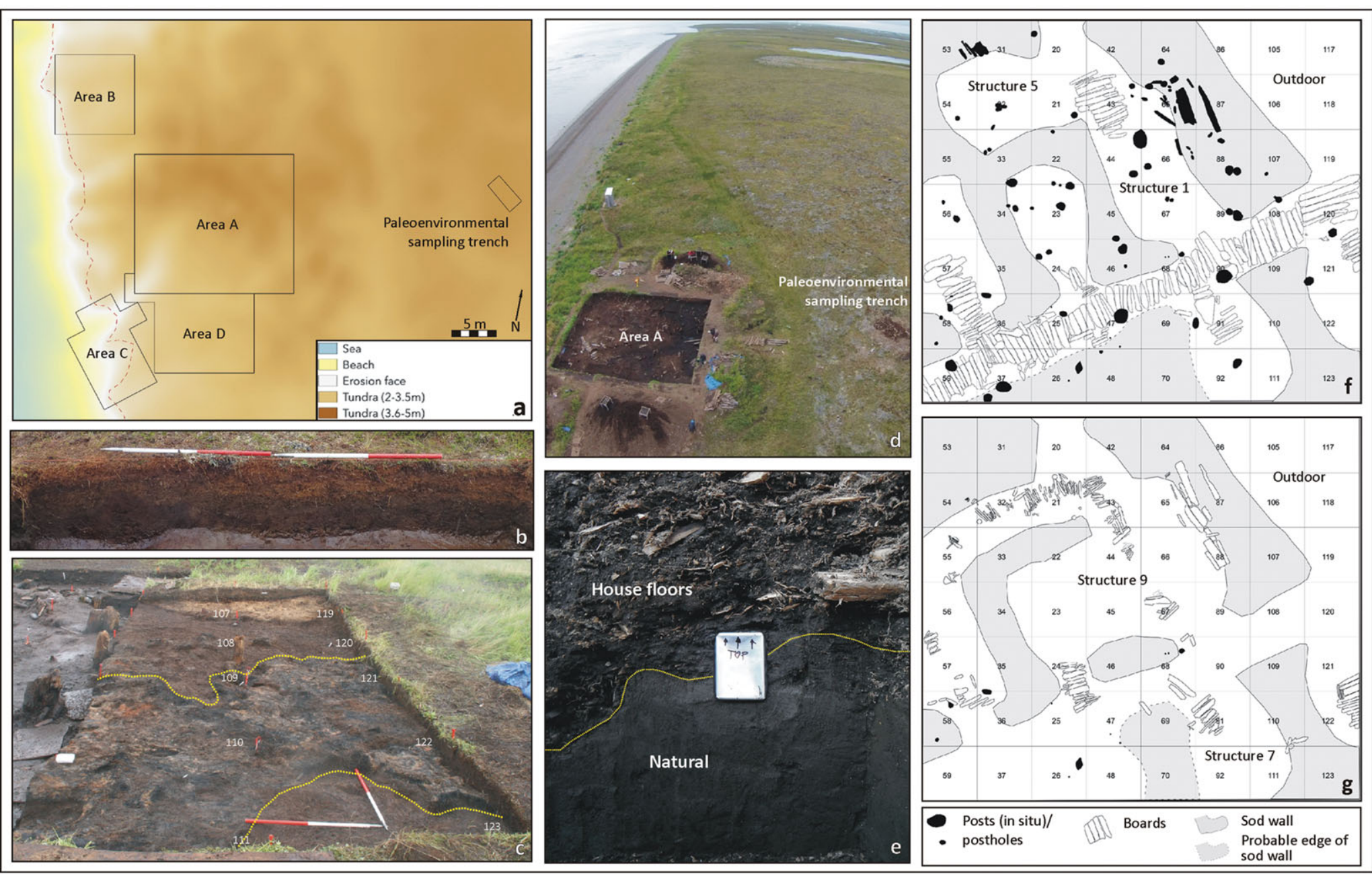

Figure 2. (a) Digital elevation model illustrating the locations of each of the excavation areas, paleoenvironmental sampling, and the extent of erosion since 2009; (b) the paleoenvironmental sampling trench illustrating the absence of archaeological features; (c) charred sod (indicated by yellow dashed lines) evident in Squares 111-107 and 123-119 of Area A; (d) aerial photograph of the site taken immediately prior to backfilling at the end of the 2015 field season; (e) sampling of the contact between natural and archaeological (indicated by yellow dashed line) deposits in Square 59 in 2015; and (f, g) planform of the Area A dwelling in occupation Phases II and III, respectively. Photographs and maps by the authors. (color online) 


\begin{tabular}{|c|c|c|c|}
\hline \multicolumn{2}{|c|}{ Archaeological Phase } & \multicolumn{2}{|c|}{ Event } \\
\hline \multirow[t]{3}{*}{$\mathbf{I}$} & \multirow[t]{3}{*}{ Recent } & A & Modern vegetation \\
\hline & & B & Looting \\
\hline & & $\mathrm{C}$ & Peat growth \\
\hline \multirow[t]{4}{*}{ II } & \multirow[t]{4}{*}{ Latest occupation } & D & Collapse \\
\hline & & $\mathrm{E}$ & Attack \\
\hline & & $F$ & Occupation \\
\hline & & G & Remodeling \\
\hline \multirow[t]{2}{*}{ III } & \multirow[t]{2}{*}{ Middle occupation } & H & Occupation \\
\hline & & 1 & Construction \\
\hline \multirow[t]{3}{*}{ IV } & \multirow[t]{3}{*}{ Early occupation } & $\mathbf{J}$ & Remodeling/Abandonment \\
\hline & & $\mathrm{K}$ & Occupation \\
\hline & & $\mathrm{L}$ & Construction \\
\hline
\end{tabular}

Figure 3. Interpretative summary of the relative sequence of events at Nunalleq. Italicized events reflect unexcavated deposits.

events (Phases II, III, and IV) are evident in this building (Figure 3). Deposits associated to Phase IV have yet to be excavated, but the uppermost house floors and walls of this phase were exposed at the end of the 2015 field season. During this season a small sondage $(2 \times 1 \mathrm{~m})$ was cut in Square 59 to prove the natural geology and ascertain the remaining depth of cultural deposits. This trench identified natural deposits at $0.4 \mathrm{~m}$ below the top of Phase IV, and the interface was sampled using a Kubiena tin to obtain dating material for the earliest occupation (Figure 2). The two subsequent occupation phases, III and II, were excavated in their entirety in Area A from 2013 to 2015 .

The interface between Phase III and Phase IV (the earliest occupation) was defined by a thick (up to $20 \mathrm{~cm}$ ) layer of debris interpreted as a hiatus in the occupation of the dwelling, or a wholescale remodeling of the structure. The walls and other architectural features belonging to Phase III were therefore built over the leveled remains of the earlier sod dwelling complex. The features excavated indicate that the sod building could be accessed through an entryway located to the east, which led to a large $(9 \times 4$ $\mathrm{m})$ antechamber and a series of smaller rooms that were interconnected by passageways and corridors. The architecture during the most recent occupation phase (Phase II) is similar to that of Phase III. The northeastern external wall and some internal divisions were used during both phases, but there is evidence for remodeling. The most important change is the construction of a new room (Structure 5) adjacent to the former northwestern passageway (Structure 13; Figure 3). The uppermost floor levels of Phase II were charred in many locations and interpreted as reflecting the habitation surfaces contemporary with the attack (Event E) that destroyed the village. Associated with Phase II are human remains excavated in outdoor deposits northeast of the external wall and capped by peat growth. The refuse deposits (Area B) represent the infilling of 
an older structure, and their temporal relationship with other areas is unclear. Owing to the threat posed by coastal erosion, the excavation of Areas $\mathrm{C}$ and $\mathrm{D}$ focused on maximizing the recovery of material cultural remains and detailed recording was not undertaken. As such, the relative chronology of Areas $\mathrm{C}$ and $\mathrm{D}$ and their temporal relationship with Area A are poorly defined.

\section{Material Culture}

To date, over 60,000 artifacts constructed from a variety of materials, including wood, bone, ivory, stone, and ceramic, have been recovered from Nunalleq. The majority of these objects strongly resemble nineteenth-century ethnographic collections made in the central Yup'ik area. Artifact classes that are unrepresented in ethnographic collections are rare; thus, it is highly likely the site represents an occupation by a central Yup'ik population. The assemblage provides an exceptionally broad insight into all aspects of Yup'ik lifeways such as subsistence (e.g., harpoons and sea mammal darts), transportation (e.g., kayak and sled parts), belief systems (e.g., masks, dolls, and animal figurines), storage (e.g., pottery and bentwood bowls), and warfare weaponry (e.g., projectile points and bow staves). Evidence of long-distance trading networks is also present in the form of nephrite drill bits (likely sourced from the Kobuk River, north of the Seward Peninsula), amber beads, and serpentine and other exotic raw materials. Notably absent is evidence of any Euro-American material culture, which indicates that the site almost certainly predates the arrival of Russian explorers in the Y-K delta.

\section{Existing Radiocarbon Data}

Prior to this study, a total of 33 radiocarbon assays were run on a variety of organic remains from Nunalleq (Britton et al. 2016; Ledger et al. 2016). Between 2009 and 2012, a total of 18 samples of caribou bone collagen and plant remains (wood, grass artifacts, and seeds from edible berries) from Areas B, C, and D were submitted for "range finder" dating to obtain a general understanding of the site chronology (sensu Bayliss 2009). These dates returned ages ranging from $650 \pm 40$ (Beta-263581; wood; $\delta^{13} \mathrm{C}=-25.20 \%$ ) to $182 \pm 37$ (SUERC-54993;
Rangifer tarandus; $\delta^{13} \mathrm{C}=-17.80 \%$ ) ${ }^{14} \mathrm{C} \mathrm{BP}$. A simple Bayesian model—grouping all samples as one phase-suggested occupation between the fourteenth and eighteenth centuries $\mathrm{AD}$ (Britton et al. 2016). In 2015, further radiocarbon analyses (15 in total) were undertaken to examine inter-context ${ }^{14} \mathrm{C}$ age variation of a suite of ecofacts from the terminal occupation levels of Phase II. The results indicated that caribou (Rangifer tarandus) bone collagen and seeds from edible berries (Rubus chamaemorus and Empetrum nigrum) provided the most consistent age estimates (Ledger et al. 2016). The work also confirmed previous observations regarding the MRE associated with bone collagen of marine organisms (e.g., Dumond and Griffin 2002), noted inconsistencies in the ages of grass artifacts, and highlighted wood at the site as being probable driftwood (Ledger et al. 2016). Assays undertaken on wood, grass, and indeterminable plant remains have therefore been excluded from the current study. Details of the range finder dates are presented in Ledger and others (2016).

\section{Specific Aims of the Dating Program}

Despite the existence of a suite of ${ }^{14} \mathrm{C}$ dates from Areas B, C, and D, the chronology of Nunalleq remains imprecisely defined. The occupation of the site falls within the fourteenth to eighteenth century, an unfavorable part of the calibration curve, which results in radiocarbon dates with wide 2-sigma calibrated age ranges. Compounding this is the absence of robust relative chronological information associated with these data, arising from Areas B, C, and D having been excavated as a salvage operation (Ledger et al. 2016). Therefore, the objective of this study is to use the well-contextualized stratigraphic relationships established since 2013 from Area A and apply Bayesian modeling to refine the overall occupational chronology of Nunalleq. More specifically, this study aims to (1) estimate the earliest date of activity at Nunalleq, (2) provide an age estimate for the establishment of the Area A dwelling, (3) investigate if there is evidence for a hiatus in the occupation of Nunalleq, (4) generate age estimates for the architectural remodeling of the dwelling, (5) provide an age estimate for the conflict episode 
that resulted in the destruction of the village, and (6) estimate the durations of the different phases of occupation at the site.

\section{Methodology}

\section{Field Excavation and Sampling}

Since 2013, Nunalleq has been excavated and documented using open excavation and singlecontext recording. Using this system, each stratigraphic layer (context) is fully exposed across the excavation grid, assigned a unique number, and recorded (in planform with measurements of levels) before being sampled and removed to reveal the next deposit. The stratigraphic relationships (and relative chronologies) of all archaeological deposits were recorded in a Harris matrix (e.g., Harris 1979). The Harris matrix is a record of the temporal relationship of deposits with the most recent contexts placed at the top of the diagram and the oldest at the bottom (e.g., Figure 4). The lines connecting contexts reflect direct stratigraphic contact, and adjacent elements indicate contemporary events or deposition. The provenience of artifacts and large animal bones uncovered during excavation was established by recording the context number and the grid square in which they were located. Environmental sampling of house floors comprised one $18 \mathrm{~L}$ faunal sample and one large $(2 \mathrm{~L})$ General Biological Analysis (GBA) sample per context. In the case of house floors, one GBA sample was collected from each grid square (i.e., multiple samples from a context). Sampling was evenly distributed across the context and grid square (in order to sample local variation) using clean tools with samples placed into heavygauge plastic bags. During the excavation season, GBAs were stored in a cool dry space in Quinhagak before being transported to the University of Aberdeen and stored at $4^{\circ} \mathrm{C}$. Bulk faunal samples were water screened in Quinhagak using $3 \mathrm{~mm}$ mesh.

\section{Radiocarbon Dating}

Nineteen samples were selected and submitted for radiocarbon dating in this study (Supplemental Table 1). These samples focused exclusively on terrestrial animal bone collagen
(Rangifer tarandus) and plant macrofossils (Rubus chamaemorus, Empetrum nigrum seeds, and Sphagnum sp. moss). Animal bone was sampled using a hand drill and diamond-coated cutting discs at the University of Aberdeen. Plant macrofossils were isolated from GBA samples. In each instance, approximately $25 \mathrm{~mL}$ subsamples were disaggregated in a weak $\mathrm{NaOH}$ solution and washed through a nest of sieves. The residues were examined under a binocular microscope to identify macrofossil remains for dating. Samples were cleaned to remove roots and other extraneous matter before being stored in slightly acidified water and submitted to the Oxford Radiocarbon Accelerator Unit (ORAU) for dating. Isotopic fractionation was corrected for using the $\delta^{13} \mathrm{C}$ values measured on the AMS, while the quoted $\delta^{13} \mathrm{C}$ values were measured independently on a stable isotope mass spectrometer. Conventional ${ }^{14} \mathrm{C}$ ages (Stuiver and Polach 1977) are presented and quoted according to the international standard of the Trondheim convention (Stuiver and Kra 1986). All radiocarbon dates were calibrated in OxCal v.4.3.2 (Bronk Ramsey 2009) using the IntCal13 calibration curve (Reimer et al. 2013) and rounded to the nearest five years.

\section{Bayesian Analyses}

The Bayesian analyses employed in this study were undertaken within the program OxCal v.4.3.2. (Further information on the methodology and algorithms used by OxCal can be found in Bronk Ramsey [1995, 1998, 2001, 2009].) It is important to stress that this methodology produces interpretative estimates established on the basis of available data; therefore, results may change as data becomes available or is modeled from alternate perspectives (Bayliss 2009). In OxCal, the stability of a model is measured in the form of the $A_{\text {model }}$ agreement index. Values over 60 are considered to indicate an acceptable agreement between the radiocarbon data and prior (e.g., stratigraphic) information, which forms the basis of the model (Bayliss 2009; Bronk Ramsey 1995). Individual agreement indices are also generated for each radiocarbon date to allow an evaluation of how the posterior (modeled) date agrees with the prior (calibrated) date of a sample. Typically, individual agreement indices 


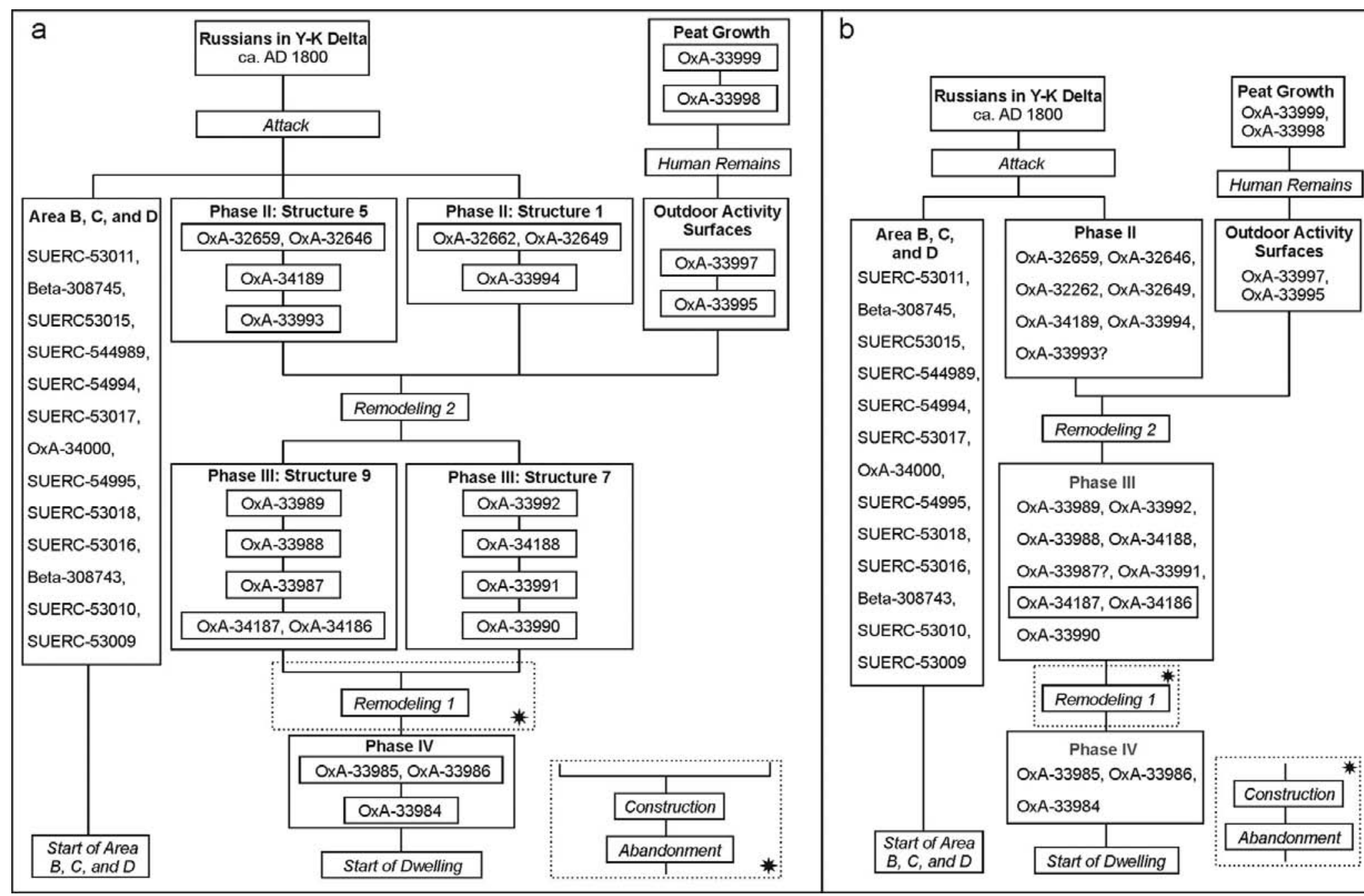

Figure 4. (a) Summary of the prior information incorporated into Models A1 and B1. The major differences between the two models relate to the treatment of the transition from Phase IV to III indicated within the dotted box. In Model B (inset), a hiatus between these two phases is included in the model. Stratigraphic relationships are shown beginning with earliest (oldest) at the base and latest (youngest) samples at the top. (b) Summary of the prior information incorporated into Models A2 and B2, the results of which are presented in Figures 5 and 6 . In these models, the stratigraphy has been simplified to remove individual house floor sequences and treat all measurements from individual occupation phases as a single phase of activity. The key differences between Models A2 and B2 relate to the treatment of the transition from Phase IV to III indicated within the dotted box. In Model B2 (inset), a hiatus between these two phases is included in the model. Stratigraphic relationships are shown beginning with earliest (oldest) at the base and latest (youngest) samples at the top. Question marks indicate a date classified as an outlier. 
should also be greater than 60 , although where there is a high overall agreement index, a case may be made for the inclusion of dates that do not meet this threshold (Hamilton and Kenney 2015).

\section{Model Construction and Sample Selection}

Two models (A and B) were created to investigate different scenarios for the occupation of Nunalleq. The key difference between these models relates to the archaeological interpretation of the relationship between Phases IV and III. The interface between these two phases of occupation was differentiated by thick debris deposits (Context 15058) and marked differences in the layout of the walls and boardwalks. The debris layer is alternatively interpreted as arising due to massive remodeling of the structure, as part of an uninterrupted occupation (Model A) or a hiatus in the occupation (Model B). The construction of both models is relatively simple and a summary of the prior information is presented in Figure 4a. The basic structure of both models is identical (the major differences are discussed below) and consists of three crossreferenced OxCal sequences. Sequence: Area A Dwelling serves as the anchor for the model and is based on the area excavated between 2013 and 2015 using single-context recording. Sequence: Areas B, C, and D comprises the dates on samples excavated between 2009 and 2012, while Sequence: Outdoor activity surfaces is an accumulation of cultural deposits, human remains, and peat outside the dwelling.

Area A Dwelling. The dwelling excavated in Area A is represented by a Sequence of three Phases, which represent the main occupation phases of the dwelling (Phases IV, III, and II). These phases are then bracketed by two OxCal boundaries that generate age estimates for the beginning of the dwelling [Boundary: Start of Dwelling] and the end of occupation at Nunalleq [Boundary: Attack]. In Model A, further boundaries are located at the transitions from Phase IV/III [Boundary: Remodeling 1] and Phase III/II [Boundary: Remodeling 2] to indicate a continuous process of deposition and to generate age estimates for these events. Model B places an additional boundary between the transitions from Phase IV/III [Boundary: Abandonment] to model the possibility of a hiatus between these two phases (Figure 3). The OxCal command [Interval] is used to estimate the duration of any hiatus in Model B. A further OxCal command is placed within the overall Sequence. This command, [Before: Russians in YK Delta], is a terminus ante quem prior informing the model that the activities at Nunalleq occurred before the calendar date [C_date AD $1805 \pm 5$ ]. This prior information is determined on the basis of a complete absence of Euro-American material culture at the site (see discussion above). A further seven Difference commands are placed to generate estimates for the duration of Phases IV to II, the length of occupation of the dwelling, differences in the dates of the Area A dwelling and other structures, and the temporal relationship between the human remains and the attack.

Three separate samples of Rubus chamaemorus seeds were submitted for dating from occupation Phase IV (Figure 4). One sample is derived from the sondage trench to date the earliest house floors in the dwelling, while the others are samples from the contemporary Contexts 15170 and 15184, the latest house floors of Phase IV. Phase III is further subdivided into [Sequence: Structure 9] and [Sequence: Structure 7], which represent the major rooms of the dwelling in this phase. A series of four consecutive floors were identified in each room, and eight samples of caribou bone collagen were submitted for dating (one from each house floor). Duplicate measurements (OxA-34186 and OxA34187) were undertaken on caribou bone from the basal house floor of Structure 9 as a part of quality-control procedures at ORAU. These data were combined using the R_Combine function. Occupation Phase II is divided in two rooms modeled as [Sequence: Structure 1] and [Sequence: Structure 5]. In both instances, seeds and caribou bone collagen from the most recent floors had previously been dated (four samples in total, two from each floor) as a part of the singlecontext study (see Ledger et al. 2016 for details). In addition to these existing data, three samples of caribou bone were selected to date underlying floors (Supplemental Table 1).

Outdoor Activity Area. The outdoor activity surfaces form part of the Area A excavation unit, and the beginning of their accumulation is 
concurrent with the transition from Phase III to II. The beginning of [Sequence: Outdoor Activity] is therefore cross-referenced to equal the [Boundary: Remodeling 2/Remodeling] from [Sequence: Area A Dwelling] that marked the transition from occupation Phase III to II. Two phases of accumulation are placed within this sequence: [Phase: Outdoor Surfaces] representing the cultural deposits outside the dwelling and [Phase: Peat Growth]. The OxCal Date function is placed between these phases to estimate when the human remains were deposited. Two outdoor activity surfaces containing cultural material were identified, and a sample of Rubus chamaemorus seeds was dated from each. In addition, two distinct layers of Sphagnum sp. moss were identified overlying the human remains, and a sample of each layer was submitted for dating.

Areas $B, C$, and $D$ (Range Finder Data). This sequence comprises a single phase [Phase: Range finders] containing ${ }^{14} \mathrm{C}$ data from Areas B, C, and D (see Ledger et al. 2016 for details) within two OxCal boundaries. The first Boundary is placed to generate an estimate for the beginning of activity at Nunalleq [Boundary: Start of Areas B, C, and D] on the basis of these data. The second boundary is then crossreferenced to [Sequence: Area A Dwelling] to equal the date of the [Boundary: Attack]. The charred deposits covering the terminal floors in Area A also extended across Areas B, C, and D. Therefore, the date of the attack that destroyed Nunalleq can reasonably be assumed to contemporary across the site.

\section{Results}

\section{Radiocarbon Data}

In total, there are 19 new radiocarbon determinations associated with this study (Supplemental Table 1). In general, the results are consistent with their stratigraphic position and the results of measurements from Areas B and C (Ledger et al. 2016). The youngest date was $129 \pm 26$ ${ }^{14}$ C BP (OxA-33999; Sphagnum sect. Acutifolia moss; $\delta^{13} \mathrm{C}=-23.96 \% ; 2 \sigma$ cal AD 1680 1940) from Context 15006, which capped the human remains. The oldest ${ }^{14} \mathrm{C}$ age, $400 \pm 27$
BP (OxA-33984; Rubus chamaemorus seeds; $\delta^{13} \mathrm{C}=-25.00 \%$; $2 \sigma$ cal AD 1440-1620), was returned on the sample of Rubus chamaemorus seeds from the house floor observed to be in contact with the natural geology at the base of Phase IV (Figure 2e). The consistency of the duplicate measurements on caribou bone collagen from Context 15105 was tested using the method of Ward and Wilson (1978). The test result $\left(T^{\prime}=0.6, v=1 ; T^{\prime}[5 \%]=3.8\right)$ indicated that the two samples were statistically consistent; thus, they were combined to provide a weighted mean age of $294 \pm 19{ }^{14} \mathrm{C}$ BP.

\section{Bayesian Modeling}

Initial runs of both models (using the prior information presented in Figure 4a) returned low agreement indices of 9.5 (Model A) and 8.2 (Model B), well below the acceptance threshold of 60. In addition, two radiocarbon results, OxA-33987 and OxA-33993, were highlighted as clear outliers by their individual agreement indices. In both Models A and B, each of these dates returned agreement indices of 0.2. Given their stratigraphic position, these data are almost certainly outliers and do not reflect the true age of the contexts from which they were recovered. OxA-33987 derives from Context 15037, the second oldest house floor from Phase III of the dwelling, yet it returned the second youngest measurement in the data set $\left(168 \pm 25{ }^{14} \mathrm{C} \mathrm{BP}\right.$; Rangifer tarandus $; \delta^{13} \mathrm{C}=-18.68 \% ; 2 \sigma$ cal $\mathrm{AD}$ 1665-1950), suggesting the material is intrusive. Context 15037 was recorded to be a highly disturbed deposit, and it seems probable that the bone dated was originally deposited in a younger context. Conversely, OxA-33993 $\left(385 \pm 27{ }^{14} \mathrm{C}\right.$ $\mathrm{BP}$; Rangifer tarandus; $\delta^{13} \mathrm{C}=-18.68 \% ; 2 \sigma$ cal AD 1445-1630) was recovered from a house floor (Context 14081) in Phase II, the latest phase of the dwelling, suggesting it is residual (sensu Bayliss 2009). Context 14081 was rich in dog fur, and the bone dated was heavily chewed and highly degraded. The bone in question may therefore have been curated by a dog before it was deposited in Context 14081.

Following the results of the initial model runs, OxA-33987 and OxA-33993 were classified as outliers and a second run of both models (A1 and B1) was undertaken. These model runs produced 
results that indicated good agreement between the radiocarbon results and prior information with respective agreement indices $\left(\mathrm{A}_{\text {model }}\right)$ of 93.7 (Model A1) and 79 (Model B1). Two samples were highlighted as potential outliers. The first of these (OxA-33988; $232 \pm 26{ }^{14} \mathrm{C} \mathrm{BP}$; Rangifer tarandus; $\delta^{13} \mathrm{C}=-17.57 \% ; 2 \sigma$ cal $\mathrm{AD}$ 1640-1950) returned agreement indices of 50.7 and 51.9 in Models A1 and B1. The situation was similar for OxA-33984 $\left(400 \pm 27{ }^{14} \mathrm{C}\right.$; Rubus chamaemorus $; \delta^{13} \mathrm{C}=-25 \% ; 2 \sigma$ cal AD 1440 1620 ), the basal sample from the dwelling, where the respective agreement indices were 48.5 and 40.3. A consideration of the taphonomy of these samples and their archaeological contexts gives no clear reason to suspect that these dates are inaccurate. These data likely returned low agreement indices due to the complex nature of the stratigraphy modeled (Figure 4a). Therefore, the prior information incorporated into the model was adjusted to account for the possibility of mixing of materials between house floors. In Models A2 and B2, the individual sequences nested within each of the phases were simplified to remove prior information relating to the stratigraphic relationship of samples within Phases IV, III, and II (Figure 4b). The results of this modeling (Figures 5 and 6) produced improved agreement indices with $\mathrm{A}_{\text {model }}$ values of 118.6 (Model A2) and 113.4 (Model B2), and these models were adopted as the preferred interpretations.

\section{Discussion}

\section{The Early Years: Establishment and an Occupational Hiatus?}

At present, the timing of Yup'ik settlement in the Y-K delta is poorly constrained (Shaw 1998). Identifying when the village at Nunalleq was first established is therefore of fundamental importance. In both Models A2 and B2, independent estimates were generated to ascertain the date for the beginning of activity at Nunalleq. The first estimate (Boundary: Start of Area B, C, and D) was based on the data from Areas B, C, and D and the second (Boundary: Start of Dwelling) on the Area A dwelling sequence (Figure 7). In all instances, the estimates for the beginning of activity at Nunalleq were similar (Table 1). Range finder data suggested a slightly earlier establishment at cal AD 1375-1610 $195.4 \%$ probability; Boundary: Start of Area B, $C$ and $D$ ) than the result from the dwelling sequence of cal AD 1430-1640 (95.4\% probability; Boundary: Start of Dwelling). These age ranges also overlap with the estimates generated from the chronological modeling of paleoenvironmental data (Ledger 2018). At a reduced probability, the estimates are divergent (Figure 7; Table 1). Both Model A2 and B2 indicate that Areas B, C, and D date from cal AD 1415-1475 (68.2\% probability; Boundary: Start of Area B, C and D), predating the establishment of the dwelling at around cal AD 1570-1635 (68.2\% probability; Boundary: Start of Dwelling). This is further evident in a comparison of these modeled dates that suggests the possibility of 15-230 years (Model A2) or 15-190 years (Model B2) between these two events $(68.2 \%$ probability; Difference: Start of Dwelling, Start of Area B, C and D).

While these data indicate it is possible that the dwelling excavated in Area A may have been a later addition to the village, caution must be exercised in interpreting these results. The earliest samples from the site produced dates that fall within a significant wiggle on the radiocarbon calibration curve that translates into sharply bimodal probability distributions. An absence of a well-defined relative chronology for Areas B, $\mathrm{C}$, and D compounds this problem, as does a sampling bias from Phase IV of the dwelling. Only three samples have been dated from this phase: two from the terminal (latest) house floors (OxA33985 and OxA-33990) and one (OxA-33984) from an early house floor (Figure 4). These factors and an absence of prior information regarding the relative age of dates from Areas B, C, and $\mathrm{D}$ adds uncertainty into the modeling process, which may account for these differences in the modeled ages for the establishment of Nunalleq.

Model B2 (Figure 6) was used to test the proposition that the thick debris layer between Phases IV and III represents an occupational hiatus and estimate the duration of any such period. The results indicate that if there was an abandonment (Figure 8; Table 1) of Nunalleq between Phases IV and III, it occurred sometime from cal AD 1560-1650 (95\% 


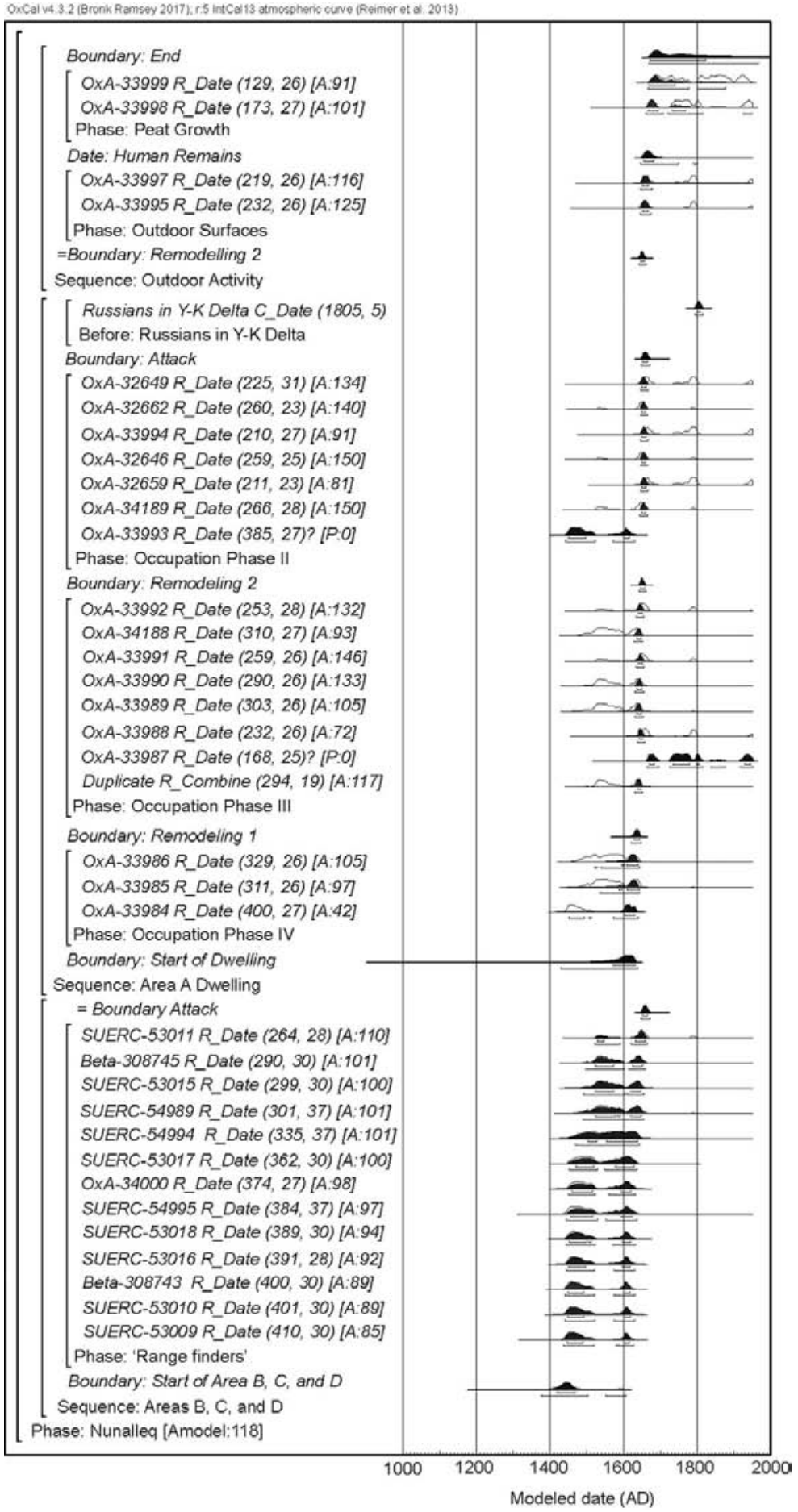

Figure 5. Model A2 probability distributions for dates and events at Nunalleq. Two distributions are plotted for each radiocarbon date: one in white with a black outline reflects the distribution based on simple radiocarbon calibration, and the other in gray reflects the posterior distribution on the basis of the chronological model used. The square brackets running down the left side and OxCal commands define the model. 


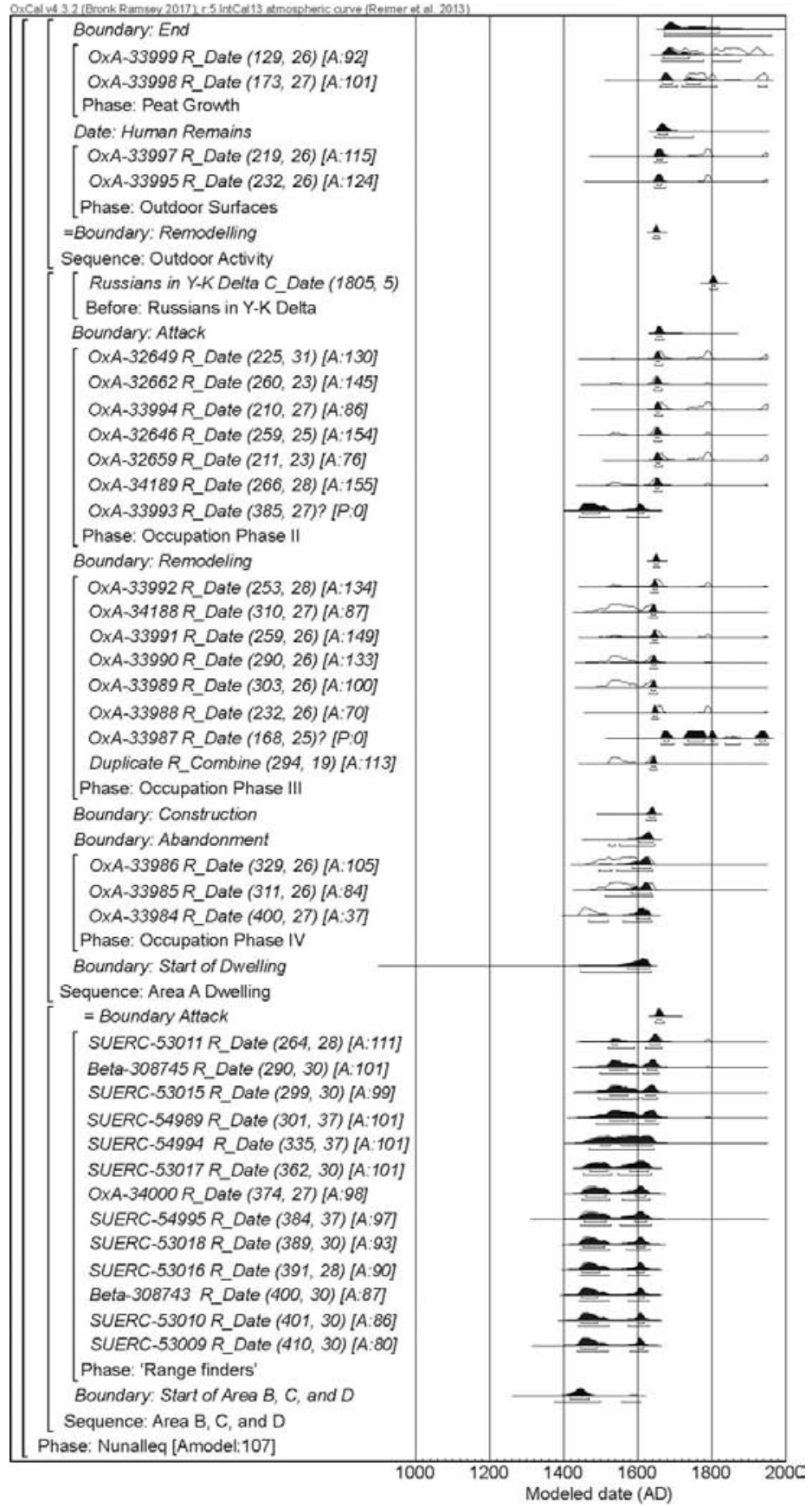

Figure 6. Model B2 probability distributions for dates and events at Nunalleq. Two distributions are plotted for each radiocarbon date: one in white with a black outline reflects the distribution based on simple radiocarbon calibration, and the other in gray reflects the posterior distribution on the basis of the chronological model used. The square brackets running down the left side and OxCal commands define the model. 
Table 1. Comparison of the Modeled Dates for Events Generated from Models A2 and B2 Rounded to the Nearest Five Years.

\begin{tabular}{llllll}
\hline & \multicolumn{2}{c}{ Model A2 } & & \multicolumn{2}{c}{ Model B2 } \\
\cline { 2 - 3 } \cline { 5 - 6 } Event & $68.2 \%(1 \sigma)$ & $95.4 \%(2 \sigma)$ & & $68.2 \%(1 \sigma)$ & $95.4 \%(2 \sigma)$ \\
\hline Human Remains & $1655-1690$ & $1650-1805$ & & $1655-1695$ & $1650-1805$ \\
Attack/End of Village & $1650-1670$ & $1645-1675$ & & $1650-1665$ & $1645-1675$ \\
Remodeling 2/Remodeling & $1645-1660$ & $1640-1660$ & & $1645-1655$ & $1640-1660$ \\
Remodeling 1/Construction & $1625-1645$ & $1620-1650$ & & $1640-1655$ & $1620-1650$ \\
Abandonment & & & & $1605-1640$ & $1560-1650$ \\
Start of Dwelling & $1570-1635$ & $1430-1640$ & & $1580-1635$ & $1465-1640$ \\
Start of Areas B, C, and D & $1415-1475$ & $1375-1610$ & & $1415-1475$ & $1385-1610$ \\
\hline
\end{tabular}

Note: All dates shown are in cal AD.

probability; Boundary: Abandonment [Model B2]) and lasted up to 75 years (95.4\% probability) or 25 years ( $68.2 \%$ probability). Therefore, there was either no hiatus in occupation, or it was short in duration. Paleoenvironmental data pertaining to human impacts at the site present evidence for a short reduction in activity about cal AD 1645 (Ledger 2018), suggesting the latter is more likely.

\section{The Later Years: Remodeling and Warfare}

The most recent period of occupation at Nunalleq (including both Phases II and III) begins with a wholescale remodeling of the dwelling. Both Models A2 and B2 (Figure 5 and 6) place the beginning of Phase III between cal AD 1620 1650 (95.4\% probability; Boundary: Remodeling/Construction). Phase III is then distinguished from Phase II by a further period of minor remodeling (Figure 3). This transition is estimated to have occurred at cal AD 1640-1660 (95.4\% probability; Boundary: Remodeling 2/Remodeling) in both Models A2 and B2. The conflict episode that resulted in the end of occupation is clearly defined in the stratigraphy of the site as a thick layer of charred sod and wood. Presumed to be associated with this event is a series of human remains. The remains comprise a cranial and limb assemblage representing at least 20 individuals along with two fully and three semiarticulated skeletons. The date of the attack (Figure 7; Table 1) is modeled to have occurred at cal $A D$ 1645-1675 in both Model A2 and B2 (95.4\% probability; Boundary: Attack/End of Occupation), while deposition of the human remains is estimated at cal $A D$ 1650-1805 (95.4\% probability; Date: Human Remains).

Date estimates for the beginning of Phases III and II and the destruction of Nunalleq present a large degree of temporal overlap implying the events likely occurred over a short period of time. The duration of Phase III is calculated to be up to 35 years in Model A2 (95.4\% probability; Difference: Remodeling 2, Remodeling 1) and as many as 30 years in Model B2 (95.4\% probability; Difference: Remodeling, Construction). The duration of Phase II is estimated to be have been shorter at a maximum of 25 years (95.4\% probability; Difference: Attack, Remodeling 2/Remodeling) in both models. A comparison of difference in the modeled ages for the attack and deposition of human remains provides a more surprising finding. The modeled difference of between -15 and 150 years $(95.4 \%$ probability; Difference: Human Remains, Attack/End of Occupation) indicates that the remains may have been deposited up to 15 years before the attack. This challenges our assumption that the skeletons represent inhabitants of Nunalleq who died in the attack that destroyed the village.

\section{How Long Was Nunalleq Occupied?}

Two calculations were made to generate estimates for the length of occupation at Nunalleq. Taking into account the data from Areas B, C, and $\mathrm{D}$, the duration of occupation (95\% probability; Difference: Attack, Start of Area B, C, and D) is estimated between $45-285$ years (Model A2) and 40-280 years (Model B2). When only the data from Area A are considered, the duration of 
OxCal v4.3.2 (Bronk Ramsey 2017); r.5 IntCal13 atmospheric curve (Reimer et al. 2013)
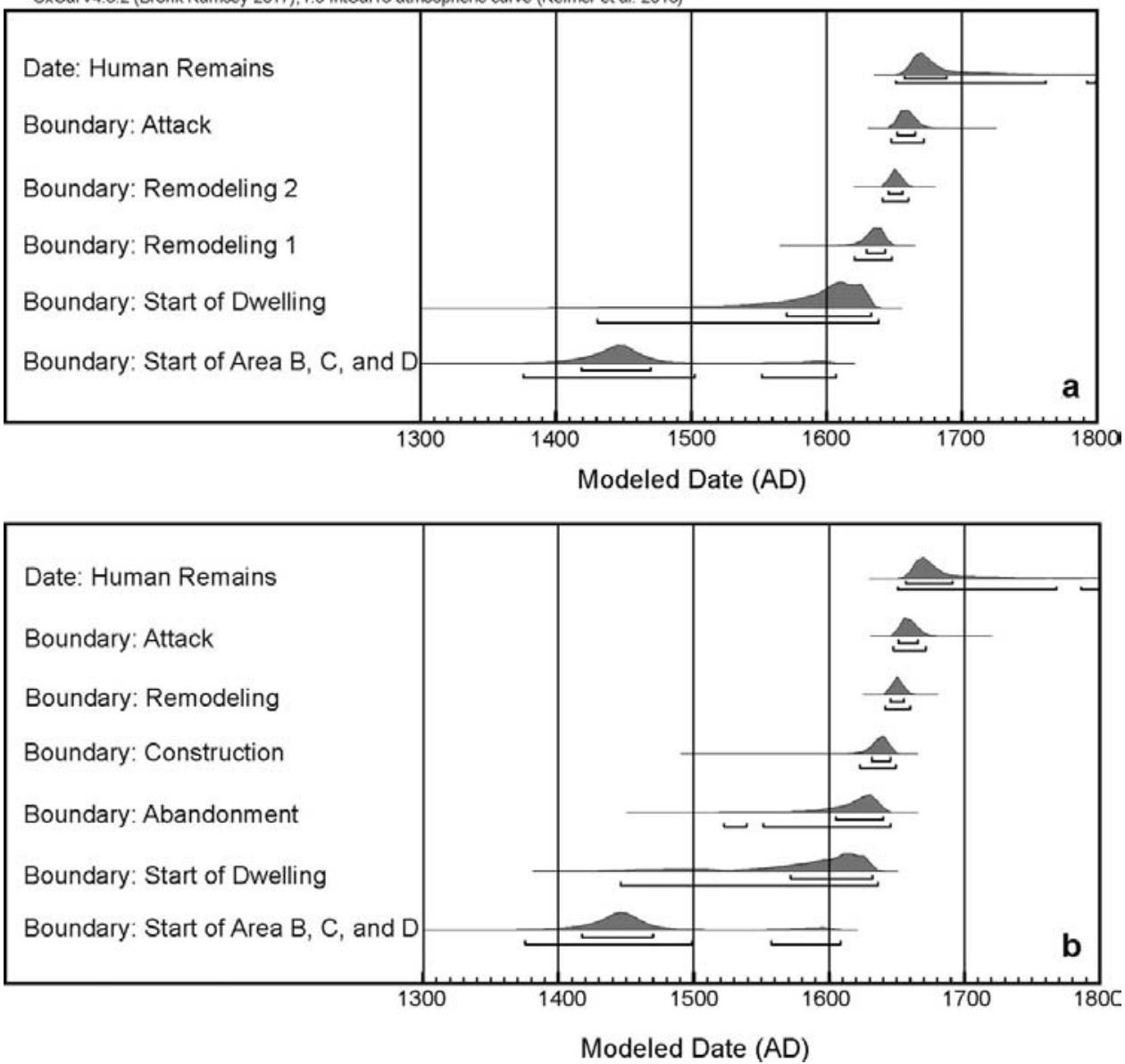

Figure 7. Posterior density estimates from (a) Model A2 and (b) Model B2 comparing the modeled dates for timing of events at Nunalleq. The results derive from the models presented in Figures 5 and 6 . Bars below the distributions indicate the $68.3 \%(1 \sigma)$ and $95.4 \%(2 \sigma)$ probabilities.

settlement is suggested to be as short as 15 years and as long as 230 years $(95.4 \%$ probability; Difference: Attack, Start of Dwelling). The wideranging nature of these estimates is, for the most part, related to the previously discussed calibration curve issues and sampling bias in Phase IV. When the estimates for the durations of Phases II and III of the dwelling (Table 2) are considered, an occupation period of over 200 years appears unlikely. Indeed, the modeled distributions for beginning of dwelling (Boundary: Start of Dwelling) and duration of activity (Difference: Attack, Start of Dwelling) have extremely long-tailed distributions producing the wide age ranges (Figures 7 and 8) as a result of the aforementioned issues. If the probability is reduced, the dwelling is estimated to have been occupied for a more plausible 20-90 years in Model A2 and 25-80 years in Model B2 (68.2\% probability; Difference: Attack, Start of Dwelling).

A shorter period of occupation for both the dwelling and the site may also be consistent with observations from the material culture. Stylistic variation in artifacts recovered from across the site, including the Area A dwelling and Areas $\mathrm{B}, \mathrm{C}$, and $\mathrm{D}$, is limited. In addition, a series of five distinctive ownership marks are found on artifacts from all phases of the dwelling complex excavated to date. Together these suggest that the majority of artifact manufacture at Nunalleq may have been undertaken by a small pool of 

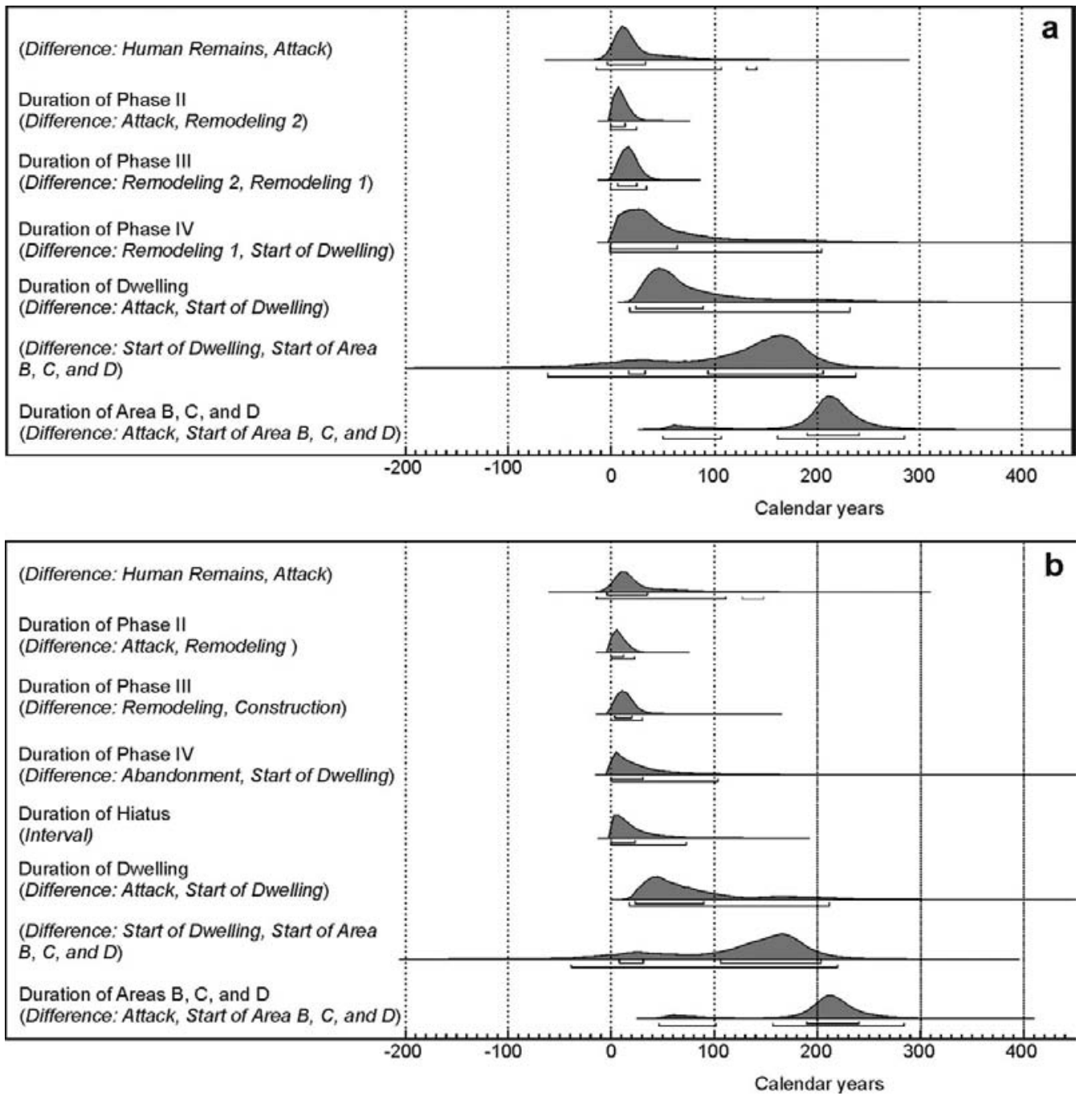

Figure 8. Comparing the probability distributions of the number of years during which various activities occurred at Nunalleq for (a) Model A2 and (b) Model B2. The distributions are based on the models shown in Figures 5 and 6.

individuals or family groups. The dwelling at Nunalleq, occupied for no more than 90 years, may have been used by perhaps as few as three generations living under the same roof. Whether there were older structures within the wider village that were occupied for longer is currently unknown. Nevertheless, different modeled ages for the start of the village and the start of the dwelling (Figure 8 ) suggest the possibility that structures older than the Area A dwelling might have existed elsewhere at the site. This will only be clarified through further excavation at Nunalleq.

\section{Conclusions}

This article has presented Bayesian analysis of radiocarbon data from a Thule-era site demonstrating the hitherto unexplored potential of such methods to refine chronological interpretation of archaeological sites in circumpolar North America. Where suitably stratified deposits exist and detailed recording of relative chronological relationships is undertaken, it is possible to generate estimates both for the timing and duration of archaeological events. The late prehistoric chronology of the Yup'ik culture region 
Table 2. Comparison of the Difference in the Modeled Durations of Events at Nunalleq in Models A2 and B2 with Ages Rounded Out to the Nearest Five Years.

\begin{tabular}{|c|c|c|c|c|}
\hline \multirow[b]{2}{*}{ Event } & \multicolumn{2}{|c|}{ Model A } & \multicolumn{2}{|c|}{ Model B } \\
\hline & $68.2 \%(1 \sigma)$ & $95.4 \%(2 \sigma)$ & $68.2 \%(1 \sigma)$ & $95.4 \%(2 \sigma)$ \\
\hline $\begin{array}{l}\text { Time Elapsed from Attack to Human Remains } \\
\text { (Difference: Human Remains, Attack) }\end{array}$ & $-5-35$ & $-15-145$ & $-5-40$ & $-15-150$ \\
\hline $\begin{array}{l}\text { Duration of Phase II } \\
\text { (Difference: Attack, Remodeling 2/Remodeling) }\end{array}$ & $1-15$ & $1-25$ & $1-15$ & $1-25$ \\
\hline $\begin{array}{l}\text { Duration of Phase III } \\
\text { (Difference: Remodeling 2/Remodeling, } \\
\text { Construction/Remodeling 1) }\end{array}$ & $5-25$ & $1-35$ & $1-20$ & $1-30$ \\
\hline $\begin{array}{l}\text { Duration of Abandonment } \\
\text { (Interval, Duration of Hiatus) }\end{array}$ & & & $0-25$ & $0-75$ \\
\hline $\begin{array}{l}\text { Duration of Phase IV } \\
\text { (Difference: Abandonment/Remodeling, Start of } \\
\quad \text { Village) }\end{array}$ & $1-65$ & $1-205$ & $1-35$ & $1-105$ \\
\hline $\begin{array}{l}\text { Time difference Dwelling and Areas B, C, and } \\
\mathrm{D} \\
\text { (Difference: Start of Dwelling, Start of Area B, } \\
\text { C, and D) }\end{array}$ & 20-205 & $-60-240$ & $10-200$ & $-35-225$ \\
\hline $\begin{array}{l}\text { Duration of Dwelling } \\
\text { (Difference: Attack, Start of Dwelling) }\end{array}$ & $20-90$ & $15-230$ & $25-80$ & $15-190$ \\
\hline $\begin{array}{l}\text { Duration of Area B, C, and D } \\
\text { (Difference: Attack, Start of Area B, C, and D) }\end{array}$ & $185-245$ & $45-285$ & $55-245$ & $40-280$ \\
\hline
\end{tabular}

Note: All modeled event durations are presented in calendar years.

of southwestern Alaska is poorly defined through a small collection of sites and a few radiocarbon dates with wide margins of error. The addition of over 30 new radiocarbon dates and Bayesian modeling to sub-centennial precision at Nunalleq therefore provide valuable new chronological data from a Yup'ik cultural context in the Y-K delta.

The results presented here indicate that people were living at Nunalleq from at least circa AD 1570-1630, although potentially as early as the fifteenth century. Bayesian modeling further suggests that Nunalleq was occupied for between 25 and 90 years, potentially encompassing as few as three generations. Evidence for an occupational hiatus prior to widespread architectural modifications dating from cal AD 1620 to 1650 is equivocal, although any abandonment is likely to have been short-lived. Further modification of the structure is estimated to have been undertaken between cal $A D 1640$ and 1660. These estimates, suggesting the possibility of a short duration of occupation that encompassed up to two remodeling episodes, provides valuable empirical data on the longevity of Yup'ik dwellings. Indeed, they illustrate that deep stratigraphy is no indicator of antiquity and chime with emerging interpretations of Thule-era architecture. The destruction of Nunalleq as a result of conflict associated with the ethnographically well-documented Bow and Arrow Wars is placed somewhere between cal $A D 1645$ and 1675.

Bayesian modeling is a probabilistic tool, and as was noted at the outset, the conclusions of this work are subject to change as new data become available. Excavations at Nunalleq are ongoing, and it is hoped that new findings will both refine and challenge the interpretations presented here, particularly in relation to the earliest period of occupation. Going forward, this article provides a framework that will permit fine-grained, diachronic analyses that are only just beginning to explore the precontact lifeways and culture of the Yup'ik occupation at Nunalleq.

Acknowledgments. This research was funded through an Arts and Humanities Research Council grant (AH/K006029/ 1) awarded to Drs. Rick Knecht, Charlotta Hillerdal, and Kate Britton, and two NERC Radiocarbon Facility grants 
(NF/2015/1/6 and NF/2015/2/3) awarded to Drs. Rick Knecht and Paul Ledger. Véronique Forbes received funding from the European Union's Horizon 2020 research and innovation program under the Marie Sklodowska-Curie grant agreement number 703322. Excavations at Nunalleq have also benefited from the support of the local community who have made us all feel at home in Quinhagak. In particular, we wish to thank Qanirtuuq Incorporated and Warren Jones for logistical support and their consistently warm hospitality. Thanks also to Philip Ashlock who took the aerial image presented in Figure 3. We also wish to acknowledge the contribution of all of the students and researchers who have excavated at Nunalleq between 2009 and 2015. Without their hard work and dedication, in sometimes challenging conditions, this article would not have been possible. Finally, we wish to thank three anonymous reviewers and Robert Kelly for constructive criticism that has helped improved this manuscript. Permission for excavations at Nunalleq was granted by Qanirtuuq Incorporated.

Data Availability Statement. The radiocarbon data used in this study are available upon request from the corresponding author and are presented in Supplemental Table 1. All artifacts excavated at Nunalleq will be housed at the Nunalleq Archaeological and Cultural Center in Quinhagak, which is scheduled to open in May 2018.

Supplementary Materials. For supplementary material accompanying this paper, visit https://doi.org//10.1017/aaq. 2018.14.

Supplemental Table 1. Nunalleq Sample Details and Radiocarbon and Stable Isotope Data.

\section{References Cited}

Bayliss, Alex

2009 Rolling Out the Revolution: Using Radiocarbon Dating in Archaeology. Radiocarbon 51:123-147.

2015 Quality in Bayesian Chronological Models in Archaeology. World Archaeology 47:677-700.

Bayliss, Alex, Christopher Bronk Ramsey, Johannes van der Plicht, and Alasdair Whittle

2007 Bradshaw and Bayes: Towards a Timetable for the Neolithic. Cambridge Archaeology Journal 17:1-28.

Black, Lydia

1984 The Yupik of Western Alaska and Russian Impact. Études/Inuit/Studies 8:21-43.

Britton, Kate, Ellen McManus-Fry, Olaf Nehlich, Mike P. Richards, Paul M. Ledger, and Richard A. Knecht

2016 Stable Carbon, Nitrogen and Sulphur Isotope Analysis of Permafrost Preserved Human Hair from Rescue Excavations $(2009,2010)$ at the Precontact Site of Nunalleq, Alaska. Journal of Archaeological Science: Reports. DOI:10.1016/j.jasrep.2016.04.015, accessed January 31, 2018.

Bronk Ramsey, Christopher

1995 Radiocarbon Calibration and Analysis of Stratigraphy: The OxCal Program. Radiocarbon 37:425-430.

1998 Probability and Dating. Radiocarbon 40:461-474.

2001 Development of the Radiocarbon Calibration Program. Radiocarbon 43:355-363.
2009 Bayesian Analysis of Radiocarbon Dates. Radiocarbon 51:337-360.

2017 OxCal Application. Electronic document, https:// c14.arch.ox.ac.uk/oxcal/OxCal.html, accessed January 31, 2018.

Darwent, John, Christyann Darwent, Kelly A. Eldridge, and Jason I. Miszaniec

2017 Recent Archaeological Investigations near the Native Village of Shaktoolik, Norton Sound, Alaska. Arctic 69:1-16.

Dumond, Don E., and Dennis G. Griffin

2002 Measurements of the Marine Reservoir Effect on Radiocarbon Ages in the Eastern Bering Sea. Arctic 55:77-86.

Dumond, Don E., and James W. VanStone

1995 Paugvik: A Nineteenth-Century Native Village on Bristol Bay, Alaska. Fieldiana Anthropology New Series No. 24. Field Museum of Natural History, Chicago.

Fienup-Riordan, Ann, and Alice Rearden

2016 Anguyiim Nalliini/Time of Warring: The History of the Bow and Arrow Wars in Southwest Alaska. University of Alaska Press, Fairbanks.

Fienup-Riordan, Ann, Alice Rearden, and Melia Knecht

2015 Irr'inarqellriit/Amazing Things: Quinhagak Elders Reflect on their Past. Alaska Journal of Anthropology 13:37-70.

Forbes, Véronique, Kate Britton, and Richard A. Knecht

2014 Preliminary Archaeoentomological Analyses of Permafrost-Preserved Cultural Layers from the Precontact Yup'ik Eskimo Site of Nunalleq, Alaska: Implications, Potential and Methodological Considerations. Environmental Archaeology 20:158-167.

Friesen, Max, and Owen Mason

2016 Introduction: Archaeology of the North American Arctic. In The Oxford Handbook of the Prehistoric Arctic, edited by Max Friesen and Owen Mason, pp. 1-17. Oxford University Press, New York.

Hamilton, W. Derek, Colin Haselgrove, and Chris Gosden

2015 The Impact of Bayesian Chronologies on the British Iron Age. World Archaeology 47:1-19.

Hamilton, W. Derek, and Jane Kenney

2015 Multiple Bayesian Modelling Approaches to a Suite of Radiocarbon Dates from Ovens Excavated at Ysgol yr Hendre, Caernarfron, North Wales. Quaternary Geochronology 25:72-82.

Hamilton, W. Derek, and Anthony M. Krus

2017 The Myths and Realities of Bayesian Chronological Modelling. American Antiquity. DOI:10.1017/ aaq.2017.57, accessed January 7, 2018.

Harris, Edward C.

1979 Principles of Archaeological Stratigraphy. Academic Press, London.

Higham, Thomas F. G., Roger Jacobi, Laura Basell, Christopher Bronk Ramsey, Laurent Chiotti, and Roland Nespoulet

2011 Precision Dating of the Palaeolithic: A New Radiocarbon Chronology for the Abri Pataud (France), a Key Aurignacian Sequence. Journal of Human Evolution 61:549-563.

Knecht, Richard A.

2014 Nunalleq: Rescuing an Eskimo Village from the Sea. British Archaeology May/June:42-49.

Ledger, Paul M.

2018 Are Circumpolar Hunter-Gatherers Visible in the Palaeoenvironmental Record? Pollen Analytical 
Evidence from Nunalleq, Southwestern Alaska. Holocene 28:415-426.

Ledger, Paul M., Véronique Forbes, Edouard MassonMaclean, and Richard A. Knecht

2016 Dating and Digging Stratified Archaeology in Circumpolar North America: A View from Nunalleq, Southwestern Alaska. Arctic 69:378-390.

Nelson, Edward W.

1899 The Eskimo about Bering Strait. Bureau of American Ethnology Annual Report 18. US Government Printing Office, Washington, DC.

Oswalt, Wendell $\mathrm{H}$.

1980 Kolmakovskiy Redoubt: The Ethnoarchaeology of a Russian Fort in Alaska. Monumenta Archaeologica Vol. 8. Institute of Archaeology, University of California, Los Angeles.

Postinikov, Alexey, and Marvin Falk

2015 Exploring and Mapping Alaska: The Russian American Era, 1741-1867. Translated by Lydia Black. University of Alaska Press, Fairbanks.

Pratt, Kenneth

2013 Deconstructing the Aglurmiut Migration: An Analysis of Accounts from the Russian-America Period to the Present. Alaska Journal of Anthropology 11:17-36.

Reimer, Paula J., Edouard Bard, Alex Bayliss, J. Warren Beck, Paul G. Blackwell, Christopher Bronk Ramsey, Caitlin E. Buck, Hai Cheng, R. Lawrence Edwards, Michael Friedrich, Pieter M. Grootes, Thomas P. Guilderson, Haflidi Haflidason, Irka Hajdas, Christine Hatté, Timothy J. Heaton, Dirk L. Hoffmann, Alan G. Hogg, Konrad A. Hughen, K. Felix Kaiser, Bernd Kromer, Sturt W. Manning, Mu Niu, Ron W. Reimer, David A. Richards, E. Marian Scott, John R. Southon, Richard A. Staff, Christian S. M. Turney, and Johannes van der Plicht

2013 IntCal13 and Marine13 Radiocarbon Age Calibration Curves 0-50,000 Years cal BP. Radiocarbon 55:1869-1887.
Roberts, Patrick, Nicole Boivin, Michael Petraglia, Paul Masser, Stephanie Meece, Alison Weisskopf, Fabio Silva, Ravi Korisettar, and Dorian Q. Fuller

2016 Local Diversity in Settlement, Demography and Subsistence across the Southern Indian Neolithic-Iron Age Transition: Site Growth and Abandonment at Sanganakallu-Kupgal. Archaeological and Anthropological Sciences 8:575-599.

Shaw, Robert D.

1982 The Expansion and Survival of Norton Tradition on the Yukon-Kuskokwim Delta. Arctic Anthropology 19(2):59-74.

1998 An Archaeology of the Central Yupik: A Regional Overview for the Yukon-Kuskokwim Delta, Northern Bristol Bay and Nunivak Island. Arctic Anthropology 35(1):234-246.

Stuiver, Minze, and Renne S. Kra

1986 Editorial Comment. Radiocarbon 28:ii.

Stuiver, Minze, and Henry A. Polach

1977 Reporting of ${ }^{14}$ C Data. Radiocarbon 19:355-363.

VanStone, James W.

1973 V.S. Khromchenko's Coastal Explorations in Southwestern Alaska, 1822. Fieldiana: Anthropology Vol. 64. Field Museum of Natural History, Chicago.

1984 Southwest Alaska Eskimo: Introduction. In Arctic, edited by David Damas, pp. 205-208. Handbook of North American Indians, Vol. 5, William C. Sturtevant, general editor, Smithsonian Institution, Washington, DC.

Ward, G. K, and S. R. Wilson

1978 Procedures for Comparing and Combining Radiocarbon Age Determinations: A Critique. Archaeometry 20:19-31.

Submitted November 17, 2017; Revised February 2, 2018; Accepted February 8, 2018 